\title{
What is the Role of Mannose-Binding Lectin Gene Polymorphism in the Development of Acute Post-Streptococcal Glomerulonephritis?
}

\section{Deniz Güven $\odot$ Mustafa Bak $\odot$ Erkin Serdaroglu $\odot$ Ferda Özkınay $\odot$ Ayça Aykut $\odot$}

\section{Akut Post Streptokokal Glomerülonefrit Gelişiminde Mannoz-Bağlayıcı Lektinin Rolü Nedir?}

\section{ABSTRACT}

Objective: This study aims to determine the effects of the mannose-binding lectin (MBL) gene polymorphism on the clinical and laboratory findings, response to treatment, and progress of patients with acute post-streptococcal glomerulonephritis (APSGN).

Methods: Codon 54 polymorphism found in exon 1 of the MBL gene was investigated by polymerase chain reaction-restriction fragment length polymorphism method in 110 children followed up with the diagnosis of APSGN and compared with healthy control group.

Results: The normal allele $A A$ and, the variant alleles $A B$ and $B B$ gene frequencies were determined within the APSGN group as $74.5 \%, 20 \%$ and, 5.5\%, respectively. No statistically significant difference was found with concerning to the gene polymorphism in the APSGN group when compared with the control group $(p>0.05)$. No correlation was found in the patient group between gene polymorphism and the presence of hematuria, edema, central nervous system findings, and blood pressure $(p>0.05)$. Concerning laboratory findings during the diagnosis, no correlation existed between the gene polymorphism and high levels of urea, creatine, total cholesterol, and triglycerides, low levels of albumin, and the presence of proteinuria $(p>0.05)$. Within the first years following the diagnosis, no statistically significant difference was found in the glomerular filtration rates, blood creatine levels, proteinuria levels, duration of microscopic hematuria and proteinuria between the patients with the gene polymorphism and those without the gene polymorphism ( $p>0.05)$

Conclusion: Our study determined that the MBL gene polymorphism was not important in the development, the laboratory and clinical findings, or the progression of the patients with APSGN.

Keywords: Acute post-streptococcal glomerulonephritis, mannose-binding lectin, gene polymorphism, prognosis

öz

Amaç: Bu çalışma, mannoz bağlayııı lektin (MBL) gen polimorfizminin, akut post-streptokokal glomerülonefrit (APSGN) klinik ve laboratuvar bulguları, tedaviye yanıtı ve prognozu üzerindeki etkilerini belirlemeyi amaçlamaktadır.

Yöntem: MBL geninin ekson 1'inde bulunan Codon 54 polimorfizmi, APSGN tanısı ile takip edilen 110 çocukta polimeraz zincir reaksiyon-restriksiyon fragman uzunluğu polimorfizmi yöntemi ile araştırıldı. Bulgular: APSGN grubunda normal alel $A A$ ve varyant allel $A B$ ve $B B$ gen frekansları sirasıyla $\% 74,5, \% 20$ ve \%5,5 olarak belirlendi. Kontrol grubuna göre APSGN grubunda gen polimorfizmi açısından istatistiksel olarak anlamlı iliski bulunmadı $(p>0,05)$. MBL gen polimorfizmi ile tanı sırasındaki laboratuvar bulguları olan; yüksek üre, kreatin, total kolesterol ve trigliserid düzeyleri, düşük albümin düzeyleri ve proteinüri varlığı arasında ilişki yoktu $(p>0,05)$. Tanıyı takip eden ilk yılda gen polimorfizmi olan ve olmayan hastalar arasında glomerüler filtrasyon oranları, kan kreatin düzeyleri, proteinüri düzeyleri, mikroskobik hematüri ve proteinüri süresi açııından istatistiksel olarak anlamlı fark bulunmadı $(p>0,05)$

Sonuç: Çalışmamız, MBL gen polimorfizminin APSGN gelişiminde, laboratuvar ve klinik bulgularında ve hastalığın ilerlemesinde önemli olmadığını göstermiştir.

Anahtar kelimeler: Akut post-streptokokal glomerülonefrit, mannoz bağlayıcı lektin, gen polimorfizm, prognoz
Received: 01.05.2021

Accepted: 18.05 .2021

First Publication: 20.09.2021

Cite as: Güven D, Bak M, Serdaroglu E, Özkınay $F$, Aykut A. What is the role of mannose-binding lectin gene polymorphism in the development of acute post-streptococcal glomerulonephritis? izmir $\mathrm{Dr}$. Behçet Uz Çocuk Hast. Dergisi. 2021;11(3):286-94.

Deniz Güven

SBÜ Ankara Keçiören Eğitim Araştırma Hastanesi, Pediatri Kliniği, Ankara, Türkiye deniz.guven06@hotmail.com ORCID: 0000-0002-4293-910X

M. Bak 0000-0002-0383-5623 Özel İzmir Çocuk Sağ lığı ve Çocuk Nefroloji Kliniği, İzmir, Türkiye

E. Serdaroglu 0000-0002-6863-8866 SBÜ Izmir Dr. Behçet Uz Çocuk Hastalıkları ve Cerrahisi Eğitim ve Arastırma Hastanesi, Pediatrik Nefroloji Kliniği, Izmir, Türkiye

F. Özkınay 0000-0001-7542-7787 Ege Üniversitesi Tıp Fakültesi, Pediatri Anabilim Dalı, Izmir, Türkiye

A. Aykut 0000-0002-1460-0053 Ege Üniversitesi Tıp Fakültesi, Genetik Anabilim Dali, izmir, Türkiye 


\section{INTRODUCTION}

Acute post-streptococcal glomerulonephritis (APSGN) is the most common non-suppurative and immune-mediated disease of the kidneys that is related with the nephritogenic strains of group $A$ streptococci that cause throat and skin infections ${ }^{(1)}$. APSGN can present as asymptomatic microscopic hematuria or a full-blown acute nephritic syndrome with red to brown urine, proteinuria, edema, hypertension, and acute kidney injury. The prognosis is generally favourable, particularly in children, but the long-term prognosis is not always favorable ${ }^{(1)}$.

Streptococcal contents and products are known to trigger this process, while the process has not been precisely defined. Although the mechanism of renal damage is not known, theories, such as glomerular localization of circulatory immune complexes, the molecular similarity between streptococcal and renal antigens, immune complex formation between in situ anti-streptococcal antibodies and glomerular antigens, and complement activation directly induced by deposit streptococcal antigens inside the glomerulus have been proposed ${ }^{(1-4)}$.

Many morphologic, clinical and serologic findings support the idea of APSGN is an immune complex disease. Even though the mechanism of the antigenantibody complexes in APSGN has not been delineated, it is thought that complement activation takes place through the alternative rather than the classic pathway. None of the studies have addressed the role of the lectin pathway (LP) ${ }^{(1)}$. Renal biopsies performed in typical cases involving APSGN within the $4^{\text {th }}$ week following the onset of symptoms have demonstrated MBL, C4d, and MAPS-1-positivities inside the mesangium ${ }^{(2)}$. It has been proposed that the LP, which is the third pathway of the complement system, can activate APSGN which takes place by the recognition of glucosamine residues on the bacterial wall by $\mathrm{MBL}$; however, patients with defects in $\mathrm{MBL}$ may also develop glomerulonephritis ${ }^{(3)}$. By studying nephritogenic Streptococcus pyogenes serotype M1 in APSGN patients, it has been shown that the lectin pathway of the complement system plays a role in the development of hypocomplementemia in APSGN
(4). Based on these findings, it appears that the LP is essential in the pathogenesis of APSGN ${ }^{(5)}$. This study aimed to analyze the effect of the MBL gene polymorphism on the development of APSGN, relevant laboratory, clinical findings, and disease progression.

\section{MATERIAL and METHODS}

\section{Diagnosis}

A total of 110 patients diagnosed with APSGN (39 females, 71 males) and 100 healthy controls without hypertension, renal, and/or cardiac disease were enrolled in the study. The diagnosis of APSGN was defined as the occurrence of edema, hypertension, hematuria, oliguria, decreased $\mathrm{C} 3$ in addition to increased plasma creatine levels following streptococcal upper respiratory tract or skin infection within previous 1-3 weeks. Hematuria was defined as the presence of 5 or more erythrocytes in the microscopic analysis of urine with high magnification. Hypertension was defined as systolic blood pressure being higher than 95 percentile according to appropriate age, gender and height; measured multiple times, at three visits or more. Proteinuria was defined as the presence of protein at a rate of $4 \mathrm{mg} /$ $\mathrm{m}^{2} /$ hour in 24-hour urine. Glomerular filtration rate (GFR) was evaluated by Schwartz formula. The medical records of patients were evaluated retrospectively for the following parameters: age at the time of diagnosis, history of infection, presence of macroscopic or microscopic hematuria, edema, central nervous system findings, hypertension, blood urea nitrogen (BUN) at the first visit, creatine, total cholesterol, triglycerides, C3, C4 levels, GFR. The duration of hematuria and proteinuria, GFR, BUN and creatinine levels, and blood pressure percentiles within the first year were evaluated.

\section{Molecular Analysis}

In the DNA obtained from the peripheral blood of the patient and control groups, the codon 54 polymorphism of exon 1 of the MBL2 gene was investigated by the restriction fragment length polymorphism method (separation of DNA into fragments of 
different sizes using restriction enzymes). The first exon of the MBL gene was amplified by PCR (349 bp). Primer sequences were 5'-TAGGACAGAGGGCATGCTC-3' (F) and inverse 5'-CAGGCAGTTTCCTCTGGAAGG-3' (R). The PCR product was obtained at $94^{\circ} \mathrm{C}$ for 30 seconds after denaturation at $94^{\circ} \mathrm{C}$ for $10 \mathrm{~min}$ utes, $57^{\circ} \mathrm{C}$ for 30 seconds, and 72 cycles of $72^{\circ} \mathrm{C}$ for 45 seconds with final holding at $7^{\circ} \mathrm{C}$ for 7 minutes. The PCR product thus obtained was kept at $50^{\circ} \mathrm{C}$ for 60 minutes with 5 IU of Banl restriction enzyme. The normal allele (allele A) of Banl was cut into two parts of $260 \mathrm{bp}$ and $89 \mathrm{bp}$, while the variant allele (allele B) remained uncut. The products obtained were visualized by electrophoresis on $2 \%$ agarose gel.

\section{Statistical Analysis}

Statistical analysis was performed using SPSS 15.0 software (SPSS Inc., Chicago, IL, USA). MBL genotype frequencies were compared by chi-square test, where $p<0.05$ was considered significant. ANOVA testing was used for comparison of numerical parameters between variables with multiple groups, and the Kruskal-Wallis test was used for those variables that did not have multiple groups. MBL gene polymorphism allele distribution was studied with the Hardy-Weinberg equation in the patient and control groups.

\section{RESULTS}

The study population consisted of 71 male and 39 female patients. The mean age of patients at the time of diagnosis was $7.8 \pm 3$ years (min-max: $2-15$ ). A history of streptococcal upper respiratory tract infection was present in $83(75.5 \%)$ and a history of streptococcal skin infection was present in 4 (3.6\%) patients. Macroscopic hematuria was present in 77 (70\%), edema in 91 (82.7\%), and central nervous system findings in $5(4.5 \%)$ patients. The systolic blood pressure at the time of the first visit was between 50 -90 percentiles in 31 (28.2\%), 90-95 percentiles in 7 (6.4\%), 95-99 percentiles in 21 (19.1\%), and $>99$ percentile in 51 (46\%) patients when evaluated with respect to appropriate age, gender and height. Having evaluated the diastolic blood pres- sure with respect to appropriate age, gender and height at the time of first visit, there were 47 (42.7\%) patients between 50-90 percentiles, 16 (14.5\%) between 90-95 percentiles, 11 (10\%) between 95-99 percentiles, and $36(32.7 \%)>99$ percentile. The mean (min-max) values for some laboratory parameters were as follows: BUN, $36.09 \pm 38.356 \mathrm{~g} / \mathrm{dL}$ (minmax:3-252); creatine, $1.133 \pm 1.0566 \mathrm{mg} / \mathrm{dL}$ (minmax: 0.5-9.8); C3, 23.739 \pm 14.7712 (min-max: 0.177); $C 4,17.005 \pm 6.4751$ (min-max: 6-34); total cholesterol, $147.25 \pm 38.462 \mathrm{mg} / \mathrm{dL}$ (min-max: 86-304); triglycerides, $116.31 \pm 57.072 \mathrm{mg} / \mathrm{dL}$ (min-max: 20-414); total protein, $5.921 \pm 0.8132 \mathrm{~g} / \mathrm{dL}$ (min-max: 3.7-8.2); albumin, $3.210 \pm 0.6279 \mathrm{~g} / \mathrm{dL}$ (min-max: 1.1-5); GFR $77.6 \pm 524.734 \mathrm{~mL} / \mathrm{min} / 1.73 \mathrm{~m}^{2}$ (min$\max : 11-158) ;$ and proteinuria in 24-hour urine, $24.399 \pm 42.0391 \mathrm{mg} / \mathrm{m}^{2} /$ hour (min-max:1.5-260) (Table 1).

When the patients were examined again at the end of the $1^{\text {st }}$ year, the following values were measured; GFR, $142.62 \pm 27.267 \mathrm{~mL} / \mathrm{min} / 1.73 \mathrm{~m}^{2}$ (minmax: 83-212); and blood creatine, $0.518 \pm 0.1277 \mathrm{mg} /$ $\mathrm{dL}$ (min-max: 0.3-1). The systolic blood pressure with respect to appropriate age, gender and height after 1 year was $<50$ percentile in 92 (83.6\%), and between $50-90 \mathrm{mmHg}$ in 18 (16.4\%) patients; the diastolic blood pressure was $<50$ percentile in $12(10.9 \%)$, and between $50-90$ percentiles in 98 (81\%) patients. The duration of macroscopic hematuria $(1.26 \pm 0.470$ weeks [min-max: 1-3]), microscopic hematuria (2.75 \pm 1.213 months [min-max:1-6]), and proteinuria (3.68 \pm 5.553 weeks [min-max:1-40]) was also determined (Table 1).

While AA (normal allele), AB (homozygous allele), and $\mathrm{BB}$ (variant allele) MBL codon 54 polymorphism were determined in exon 1 at rates of 82 (74.5\%), 22 (20\%) and 6 (5.5\%) in children with APSGN, these rates were $73(73 \%), 26(26 \%)$ and $1(1 \%)$ in the control group. Thus, in terms of codon 54 polymorphism in exon 1 , no statistically significant difference was found between the patient and the control group $(p=0.318)$ (Table 2).

Among children who were diagnosed with APSGN, when those with, and without $\mathrm{MBL}$ gene polymorphism ( $A A$ and $B B$ ) were compared in terms of their 
D. Güven et al. What is the Role of Mannose-Binding Lectin Gene Polymorphism in the Development of Acute Post-Streptococcal Glomerulonephritis?

Table 1. Demographic, clinical and laboratory findings, and disease progression in children diagnosed with APSGN.

\begin{tabular}{|c|c|}
\hline Parameters & APSGN cases(n=110) \\
\hline Female/Male* & $39 / 71$ \\
\hline Age of onseta & $7.825 \pm 3.027$ years (min-max:2-15) \\
\hline Upper respiratory tract infection* & $83(75.5 \%)$ \\
\hline Skin infection* & $4(3.6 \%)$ \\
\hline Macroscopic hematuria* & $77(70 \%)$ \\
\hline Edema* & $91(82.7 \%)$ \\
\hline Central nerve system findings* & $5(4.5 \%)$ \\
\hline \multicolumn{2}{|l|}{ First visit systolic blood pressure* } \\
\hline $50-90$ percentiles & $31(28.2 \%)$ \\
\hline 90-95 percentiles & $7(6.4 \%)$ \\
\hline 95-99 percentiles & $21(19.2 \%)$ \\
\hline >99 percentiles & 51 (46.4\%) \\
\hline \multicolumn{2}{|l|}{ First visit diastolic blood pressure* } \\
\hline 50-90 percentiles & $47(42.7 \%)$ \\
\hline 90-95 percentiles & $16(14.5 \%)$ \\
\hline 95-99 percentiles & $11(10 \%)$ \\
\hline >99 percentiles & $36(32.7 \%)$ \\
\hline First visit blood urea/nitrogen $(\mathrm{g} / \mathrm{dL})^{\mathrm{a}}$ & $36.09 \pm 38.356(\min -\max : 3-252)$ \\
\hline First visit creatine $(\mathrm{mg} / \mathrm{dL})^{\mathrm{a}}$ & $1.133 \pm 1.0566(\min -\max : 0.5-9.8)$ \\
\hline First visit $\mathrm{C}^{\mathrm{a}}$ & $23.739 \pm 14.7712(\min -\max : 0.1-77)$ \\
\hline First visit $\mathrm{C4}^{\mathrm{a}}$ & $17.005 \pm 6.4751(\min -\max : 6-34)$ \\
\hline First visit total cholesterol $(\mathrm{mg} / \mathrm{dL})^{\mathrm{a}}$ & $147.25 \pm 38.462(\min -\max : 86-304)$ \\
\hline First visit triglycerides $(\mathrm{mg} / \mathrm{dL})^{\mathrm{a}}$ & $116.31 \pm 57.072(\min -\max : 20-414)$ \\
\hline First visit total protein $(\mathrm{g} / \mathrm{dL})^{\mathrm{a}}$ & $5.921 \pm 0.8132(\min -\max : 3.7-8.2)$ \\
\hline First visit total albumin (g/dL) ${ }^{a}$ & $3.210 \pm 0.6279(\min -\max : 1.1-5)$ \\
\hline First visit GFR $\left(\mathrm{mL} / \mathrm{min} / 1.73 \mathrm{~m}^{2}\right)^{\mathrm{a}}$ & $77.6 \pm 524.734$ (min-max:11-158) \\
\hline First visit proteinuria in 24 -hour urine $\left(\mathrm{mg} / \mathrm{m}^{2} / \text { hour }\right)^{\text {a }}$ & $24.399 \pm 42.0391(\min -\max : 1.5-260)$ \\
\hline First year GFR $\left(\mathrm{mL} / \mathrm{min} / 1.73 \mathrm{~m}^{2}\right)^{\mathrm{a}}$ & 142. $62 \pm 27.267(\min -\max : 83-212)$ \\
\hline First year creatine $(\mathrm{mg} / \mathrm{dL})^{\mathrm{a}}$ & $0.518 \pm 0.1277(\min -\max : 0.3-1)$ \\
\hline \multicolumn{2}{|l|}{ First year systolic blood pressure* } \\
\hline $50-90$ percentiles & $92(83.6 \%)$ \\
\hline 90-95 percentiles & $18(16.4 \%)$ \\
\hline \multicolumn{2}{|l|}{ First year diastolic blood pressure* } \\
\hline$<50$ percent & $12(10.9 \%)$ \\
\hline 50-90 percentiles & $98(81 \%)$ \\
\hline Duration of macroscopic hematuria (weeks) ${ }^{a}$ & $1.26 \pm 0.470(\min -\max : 1-3)$ \\
\hline Duration of microscopic hematuria (months) ${ }^{a}$ & $2.75 \pm 1.213$ (min-max:1-6) \\
\hline Duration of proteinuria (weeks) ${ }^{\mathrm{a}}$ & $3.68 \pm 5.553(\min -\max : 1-40)$ \\
\hline
\end{tabular}

Values $^{a}$ : mean $\pm S D ;{ }^{*}$ :number of patients and percentiles. The blood pressure evaluated according to appropriate age, gender and height; measured multiple times, three visits or more.

Table 2. Distribution of MBL gene polymorphisms in children who were diagnosed with APSGN and the control group.

\begin{tabular}{lccc}
\hline Gene Polymorphisms & $\begin{array}{c}\text { APSGN } \\
(\mathbf{n}=110)\end{array}$ & $\begin{array}{c}\text { Control } \\
(\mathbf{n}=\mathbf{1 0 0 )}\end{array}$ & P Value \\
\hline AA & $82(74.5 \%)$ & $73(73 \%)$ & \\
AB & $22(20 \%)$ & $26(26 \%)$ & $0.318^{\mathrm{a}}$ \\
BB & $6(5.5 \%)$ & $1(1 \%)$ & \\
\hline
\end{tabular}

Values indicate the numbers of patients and those within the parentheses are percentiles. A chi-square test was performed between the patient and control groups. A $p<0.05$ was assumed to be statistically significant. genders, no statistically significant difference was found. The mean age at onset was $7.7927 \pm 3.02964$ years in the $A A, 7.8182 \pm 2.92178$ years in the $A B$, and $8.4 \pm 4.03733$ years in the $B B$ group without any statistically significant intergroup difference $(p>0.05)$. No relationship existed between history of streptococcal upper respiratory tract or skin infection and MBL gene polymorphism ( $p>0.05$ ). No correlation existed between a MBL gene polymorphism and following findings: macroscopic hematuria; edema; 
Table 3. Demographic, clinical and laboratory findings, and disease progression in children diagnosed with APSGN according to distribution of MBL gene polymorphisms.

\begin{tabular}{|c|c|c|c|}
\hline Parameters & AA & $A B$ & BB \\
\hline Male* $(n=71)$ & $48(69.6 \%)$ & $19(26.8 \%)$ & $4(5.6 \%)$ \\
\hline Female* $(n=39)$ & $34(87.2 \%)$ & $3(7.7 \%)$ & $2(5.1 \%)$ \\
\hline Age of onset* & $7.7927 \pm 3.02964$ & $7.8182 \pm 2.92178$ & $8.4 \pm 4.03733$ \\
\hline Upper respiratory tract infection* $(n=83)$ & $62(74.4 \%)$ & $16(19.3 \%)$ & $5(6 \%)$ \\
\hline Skin infection $(n=4)$ & $4(100 \%)$ & $0(0 \%)$ & $0(0 \%)$ \\
\hline Macroscopic hematuria* $(n=77)$ & $61(79.2 \%)$ & $13(16.9 \%)$ & $3(3.9 \%)$ \\
\hline Edema* $(n=91)$ & $67(73.6 \%)$ & $19(20.9 \%)$ & $5(5.5 \%)$ \\
\hline Central nerve system findings* $(n=5)$ & $5(100 \%)$ & $0(0 \%)$ & $0(0 \%)$ \\
\hline \multicolumn{4}{|l|}{ First visit systolic blood pressure* } \\
\hline $50-90$ percentiles $(n=31)$ & 22 (71\%) & $7(22.6 \%)$ & $2(6.5 \%)$ \\
\hline $90-95$ percentiles $(n=7)$ & $4(57.1 \%)$ & $3(42.9 \%)$ & $0(0 \%)$ \\
\hline $95-99$ percentiles $(n=21)$ & $18(85.7 \%)$ & $2(9.5 \%)$ & $1(4.8 \%)$ \\
\hline$>99$ percentiles $(n=51)$ & $38(74.5 \%)$ & $10(19.6 \%)$ & $3(5.9 \%)$ \\
\hline \multicolumn{4}{|l|}{ First visit diastolic blood pressure* } \\
\hline $50-90$ percentiles $(n=47)$ & $38(80.9 \%)$ & $8(17 \%)$ & $1(2.1 \%)$ \\
\hline $90-95$ percentiles $(n=16)$ & $11(68.8 \%)$ & $5(31.3 \%)$ & $0(0 \%)$ \\
\hline 95-99 percentiles $(n=11)$ & $7(63.6 \%)$ & $2(18.2 \%)$ & $2(18.2 \%)$ \\
\hline$>99$ percentiles $(n=36)$ & $26(72.2 \%)$ & 7 (19.45) & $3(8.3 \%)$ \\
\hline First visit blood urea/nitrogen $(\mathrm{g} / \mathrm{dL})^{\mathrm{a}}$ & $37.96 \pm 41.178$ & $34.68 \pm 30.84$ & $15.67 \pm 6.218$ \\
\hline First visit creatine $(\mathrm{mg} / \mathrm{dL})^{\mathrm{a}}$ & $1.125 \pm 1.1448$ & $1.232 \pm 0.8357$ & $0.883 \pm 0.2317$ \\
\hline First visit $\mathrm{C}^{\mathrm{a}}$ & $24.483 \pm 14.5684$ & $19.455 \pm 12.1370$ & $29.283 \pm 23.9341$ \\
\hline First visit total cholesterol $(\mathrm{mg} / \mathrm{dL})^{\mathrm{a}}$ & $145.76 \pm 39.704$ & $144.73 \pm 28.345$ & $176.83 \pm 47.131$ \\
\hline First visit triglycerides $(\mathrm{mg} / \mathrm{dL})^{\mathrm{a}}$ & $114.91 \pm 53.813$ & $114.14 \pm 33.165$ & $143.33 \pm 136.180$ \\
\hline First visit total albumin $(\mathrm{g} / \mathrm{dL})^{\mathrm{a}}$ & $3.330 \pm 0.6253$ & $3.195 \pm 0.5420$ & $2.983 \pm 0.9786$ \\
\hline First visit GFR $\left(\mathrm{mL} / \mathrm{min} / 1.73 \mathrm{~m}^{2}\right)^{\mathrm{a}}$ & $77.55 \pm 23.725$ & $75.32 \pm 29.912$ & $87.67 \pm 17.773$ \\
\hline First visit proteinuria in 24 -hour urine $\left(\mathrm{mg} / \mathrm{m}^{\mathrm{a}} / \mathrm{hour}\right)^{\mathrm{a}}$ & $24.362 \pm 43.5361$ & $27.109 \pm 42.0249$ & $24.399 \pm 42.0391$ \\
\hline First year GFR $\left(\mathrm{mL} / \mathrm{min} / 1.73 \mathrm{~m}^{2}\right)^{a}$ & $143.52 \pm 27.713$ & $139.73 \pm 26.157$ & $140.83 \pm 28.958$ \\
\hline First year creatine $(\mathrm{mg} / \mathrm{dL})^{\mathrm{a}}$ & $0.518 \pm 0.1304$ & $0.509 \pm 0.1192$ & $0.550 \pm 0.1378$ \\
\hline \multicolumn{4}{|l|}{ First year systolic blood pressure* } \\
\hline 50-90 percentiles & $68(73.9 \%)$ & $19(20.7 \%)$ & $5(5.4 \%)$ \\
\hline 90-95 percentiles & $14(77.8 \%)$ & $3(16.7 \%)$ & $1(5.6 \%)$ \\
\hline \multicolumn{4}{|l|}{ First year diastolic blood pressure* } \\
\hline$<50$ percentiles & $73(75.4 \%)$ & $20(20.4 \%)$ & $5(5.1 \%)$ \\
\hline $50-90$ percentiles & $9(75 \%)$ & $2(16.7 \%)$ & $1(8.3 \%)$ \\
\hline Duration of macroscopic hematuria (weeks) & $1.26 \pm 0.444$ & $1.15 \pm 3.76$ & $1.67 \pm 1.155$ \\
\hline Duration of microscopic hematuria (months) & $2.68 \pm 1.206$ & $2.68 \pm 1.125$ & $3.33 \pm 1.633$ \\
\hline Duration of proteinuria (weeks) ${ }^{a}$ & $4.03 \pm 6.417$ & $2.80 \pm 1.135$ & $2.50 \pm 1.732$ \\
\hline
\end{tabular}

Values ${ }^{a}$ : mean $\pm S D ;{ }^{*}:$ number of patients and percentiles. The blood pressure evaluated according to appropriate age, gender and height; measured multiple times, at three visits or more.

central nervous system findings; high systolic and diastolic blood pressures; high levels of BUN; creatine; total cholesterol and the triglycerides; the level of proteinuria in the 24-hour urine sample; low levels of C3 and albumin; GFR at the time of first visit ( $p>0.05$ ) (Table 3).

GFR and blood creatine levels of children who were diagnosed with APSGN were evaluated again at the end of the first year, and no statistically significant correlation existed between APSGN, and the presence of a MBL gene polymorphism ( $p>0.05)$. At the end of first year proteinuria was observed in 3 patients. Each one of these patients had $A A, A B$ or $B B$ allele. No statistically significant correlation was found between the MBL gene polymorphism and ongoing proteinuria $(p>0.05)$. At the end of the first year, there were no elevations in systolic and diastolic pressures in any of patients. MBL gene polymorphism did not predispose to the development of APSGN and the presence of the polymorphism did not cause severe laboratory abnormalities or clinical symptoms and it is not important in terms of disease progression (Table 3). 


\section{DISCUSSION}

MBL is a crucial component of innate immunity ${ }^{(6-8)}$. Studies related to MBL have reported that a MBL deficiency increases the risk of infection, especially in lower and upper respiratory tracts ${ }^{(9,10)}$. The higher MBL levels are crucial in terms of protection from sepsis and septic shock when different alleles compared with each other ${ }^{(11)}$. A wide variety of bacteria, fungi, viruses, and parasitic organisms have connections to $\mathrm{MBL}{ }^{(12)}$. MBL plays an important role in host defense against $N$. meningitis, $H$. influenza, Human Immunodeficiency Virus (HIV), Influenza A, Herpes simplex virus, Candida Albicans, Saccharomyces Cerevisiae, Aspergillus Fumigatus infections ${ }^{(6,13)}$. The frequency of the MBL variant allele was also evaluated in pediatric patients with infections and suspected immunodeficiency.

The MBL defect was first described in 1989 as a major opsonization defect ${ }^{(14)}$. MBL deficiency and low MBL levels have been strongly associated with three missense mutations in codons 52, 54, and 57 of exon 1 in the human MBL gene ${ }^{(11,13)}$. These mutations cause impairment in $\mathrm{MBL}$ multimerization, decrease in ligand binding and, inactivation of complement. Polymorphism has been detected in the promoter region of $\mathrm{MBL}$. These polymorphism are called $H / L, X / Y$ and, $P / Q$, and they are in positions $550,221,+4$. HYP leads to medium to high MBL production, LXP to low MBL production. While $5 \%$ of people are homozygous or heterozygous for these three types of point mutations and they have $\mathrm{MBL}$ deficiency ${ }^{(11,13,14)}$. In this defect, MBL levels are less than $100 \mathrm{ng} / \mathrm{ml}$. MBL deficiency is not a classic primary immunodeficiency, it has various regulatory mutations, and its clinical penetrance is significantly low ${ }^{(2,14)}$.

An increase in MBL levels has been correlated with autoimmune diseases such as Systemic Lupus Erythematosus (SLE), Rheumatoid Arthritis (RA), Celiac disease, Sjögren's syndrome and, Crohn's disease ${ }^{(15,16)}$. MBL deficiency increases an individual's potential vulnerability to infectious and autoimmune diseases. Considering that the MBL pathway causes a tendency for autoimmune diseases, the role of
MBL has been investigated in the development of glomerulonephritis in human beings. MBL manifests itself with immunoglobulin (Ig) $\mathrm{G}$ deposits in the kidney biopsy materials of patients with lupus nephropathy, membrane-proliferative glomerulonephritis, anti-glomerular basement membrane nephritis, focal segmental glomerulosclerosis, and IgA nephropathy ${ }^{(7)}$. It has been suggested that a MBL genetic defect can be related to the development of SLE; lower MBL levels serve as a risk factor in terms of SLE development ${ }^{(18,19)}$. In membranous nephropathy (MN) and Henoch-Schönlein Purpura nephritis, complement activation through the lectin pathway may play a role in the development of advanced glomerular injuries ${ }^{(20-22)}$. The higher levels of MBL are associate with a higher risk of acute kidney allograft rejection and the decrease in graft life expectancy ${ }^{(23)}$. Studies have investigated the role of higher levels of $\mathrm{MBL}$ in the pathogenesis of cryoglobulinemic glomerulonephritis ${ }^{(24)}$. MBL deficiency and excess can both slow the progression of Ig A Nephropathy ${ }^{(25)}$. Higher MBL levels have been correlated with the development of persistent micro-macro albuminuria and microvascular complications in early onset type-1 diabetes patients ${ }^{(26)}$. Increased MBL activation has been proposed to trigger organ damage that develops as a result of acute renal deficiency and ischemia-reperfusion and can cause a tendency for the development of atherosclerosis in patients with chronic renal insufficiency ${ }^{(27,28)}$. LP can also activate APSGN, and patients with MBL defects may develop glomerulonephritis ${ }^{(1,5)}$. MBL and C4d staining intensity in the glomerular mesangium in post-streptococcal GN determine the degree of LP activation ${ }^{(29,30)}$.

The polymorphism in the MBL gene is also associated with diseases ${ }^{(31)}$. The MBL exon 1 polymorphisms may play a role in the predisposition to SLE, progression of RA, development of leprosy and tuberculosis ${ }^{(31-34)}$. Preterm infants with MBL2 gene polymorphisms are at an increased risk of developing respiratory distress syndrome and sepsis ${ }^{(35)}$. The MBL genotypes AA for rs 180040 (G/A), GG for rs1800451 (G/A), and CC for rs5030737 (T/C) have a higher prevalence in patients infected with Coronavirus Disease 2019 (COVID-19). The patients 
with these polymorphisms and COVID-19 have a worse outcome due to the extreme activation of the lectin pathway, with a focus on the MBL pathway (36).

APSGN is known as immune-mediated disease that occurs following skin and pharyngeal infections which are related to nephritogenic strains of group a streptococci; however, the pathologic process has not been clarified yet ${ }^{(1)}$. The role of lectin cascade, which is triggered by $\mathrm{MBL}$ (the third pathway of complement system) in the development of APSGN has received considerable attention ${ }^{(2-5)}$. MBL recognizes high levels of mannose and $\mathrm{N}$-acetylglucosamine (G1CNAc) derivatives, which are located on the surface of micro-organisms. Cell wall polysaccharides bear G1cNAc as an antigenic determinant and it is thought that MBL activates the complement system by recognizing this molecule on the pathogen ${ }^{(3-5)}$. MBL can also bind to galactosamine radicals, which in turn can bind glomeruli that contain these carbohydrates covered with streptococcal neuraminidase. The lectin pathway of the complement system leads to renal damage by activation of C3 directly by MAPS-1 and C4 by MAPS-2 ${ }^{(37)}$. Recognition of lectin may be important in early pathogen invasion. Antigen is independent of the antibody system and hence can illuminate the development of APSGN (5,37). However, there is no study in the literature investigating the relationship between $\mathrm{MBL}$ gene polymorphism and APSGN. With these interactions in mind, patients who developed APSGN and healthy controls were compared in terms of MBL gene polymorphism and the importance of the lectin pathway in the pathogenesis of APSGN was investigated. In our study, it was observed that MBL polymorphism did not lead to the development of APSGN by increasing the tendency for streptococcal infections.

The studies have suggested that MBL can play a harmful as well as a beneficial role in renal diseases, sometimes it does not cause any tendency to disease progression based on clinical and laboratory entities. Because of the association between MBL and APSGN, we suspected that MBL gene polymorphism could lead to a higher risk of APSGN development in children. In this study, we looked at the codon 54 (allele B) polymorphism in the first exon of the MBL gene, its distribution, and its impact on clinical laboratory results, prognosis of APSGN and other related factors were evaluated. AA (normal allele), $A B$, and $B B$ (variant allele) gene frequencies were $74.5 \%(n: 82), 20 \%(n: 22)$ and $5.5 \%(n: 6)$, respectively in the patient group. No significant difference was found in terms of gene polymorphism when patients were compared with the control group ( $p>0.05$ ). The infectious and autoimmune origin of the disease activation was investigated because those with MBL gene polymorphisms could be predisposed to defect-related development; however, there was no statistically significant difference in terms of development of APSGN between the $A B$ (heterozygous) and $B B$ (homozygous) groups with polymorphism and the AA (normal allele) group without polymorphism ( $p>0.05)$. In patients with APSGN, no significant difference was found in terms of susceptibility to MBL gene polymorphism.

\section{CONCLUSION}

Due to association between MBL and APSGN; we investigated the role of $M B L$ gene polymorphism in the development of APSGN. Being consistent with the literature, our study also revealed that MBL gene polymorphism does not cause tendency for the development of APSGN and the presence of the polymorphism did not cause severe laboratory or clinical abnormalities and it is not important in terms of disease progression. Since the number of patients has increased and the rate of mutation increases as the level of MBL decreases, it would be valuable to perform new studies that elucidate the role of $\mathrm{MBL}$ mutation in the etiology of APSGN in children.

\section{Acknowledgments}

All the staff of Medical Genetics, Faculty of Medicine Ege University, Departments of Medical Genetics, Izmir, Turkey

Ethics Committee Approval: Izmir Dr. Behçet Uz Children's Hospital Ethics Committee approval was obtained (2008). 


\section{Conflict of Interest: None.}

Funding: No financial support was received for this study.

Informed Consent: The patients provided written informed consent for genetic analysis.

\section{REFERENCES}

1. Ellis D, Avner William e, Harmon Patrick N. Acute Proliferative Glomerulonephritis. Pediatric Nephrology. $5^{\text {th }}$ Edition. p 60111.

2. Onyewotu II, Mee J. Circulating immune complexes and complement levels in relation to the clinical presentation of Nigerian children with acute poststreptococcal glomerulonephritis. J Clin Pathol. 1978;31(9):817-22. https://doi.org/10.1136/jcp.31.9.817

3. Rodríguez-Iturbe B, Batsford S. Pathogenesis of poststreptococcal glomerulonephritis a century after Clemens von Pirquet. Kidney Int. 2007;71(11):1094-104. https://doi.org/10.1038/sj.ki.5002169

4. Skattum L, Akesson P, Truedsson L, Sjöholm AG. Antibodies against four proteins from a Streptococcus pyogenes serotype M1 strain and levels of circulating mannan-binding lectin in acute poststreptococcal glomerulonephritis. Int Arch Allergy Immunol. 2006;140(1):9-19. https://doi.org/10.1159/000091745

5. Hisano S, Matsushita M, Fujita T, Takeshita M, Iwasaki H. Activation of the lectin complement pathway in post-streptococcal acute glomerulonephritis. Pathol Int. 2007;57(6):351-7. https://doi.org/10.1111/j.1440-1827.2007.02107.x

6. Stefansson Thors V, Kolka R, Sigurdardottir SL, Edvardsson VO, Arason G, Haraldsson A. Increased frequency of C4B*QO alleles in patients with Henoch-Schönlein purpura. Scand J Immunol. 2005;61(3):274-8.

https://doi.org/10.1111/j.1365-3083.2005.01533.x

7. Dommett RM, Klein N, Turner MW. Mannose-binding lectin in innate immunity: past, present and future. Tissue Antigens. 2006;68(3):193-209. https://doi.org/10.1111/j.1399-0039.2006.00649.x

8. Ip WK, Takahashi K, Ezekowitz RA, Stuart LM. Mannosebinding lectin and innate immunity. Immunol Rev. 2009;230(1):9-21.

https://doi.org/10.1111/j.1600-065X.2009.00789.x

9. Koch A, Melbye M, Sørensen P, Homøe P, Madsen HO, $\mathrm{Møl}$ bak $\mathrm{K}$ et al. Acute respiratory tract infections and mannose-binding lectin insufficiency during early childhood. JAMA. 2001;285(10):1316-21. https://doi.org/10.1001/jama.285.10.1316

10. Chen J, Xu Z, Ou X, Wang M, Yang X, Li Q. Mannose-binding lectin polymorphisms and recurrent respiratory tract infection in Chinese children. Eur J Pediatr. 2009;168(11):130513. https://doi.org/10.1007/s00431-009-0924-1

11. Turner MW. Mannose-binding lectin: the pluripotent molecule of the innate immune system. Immunol Today. 1996;17(11):532-40. https://doi.org/10.1016/0167-5699(96)10062-1

12. Eisen DP, Minchinton RM. Impact of mannose-binding lectin on susceptibility to infectious diseases. Clin Infect Dis. 2003;37(11):1496-505. https://doi.org/10.1086/379324

13. Gadjeva M, Takahashi K, Thiel S. Mannan-binding lectin--a soluble pattern recognition molecule. Mol Immunol. 2004;41(2-3):113-21.

https://doi.org/10.1016/j.molimm.2004.03.015

14. Klein NJ. Mannose-binding lectin: do we need it? Mol Immunol. 2005;42(8):919-24.

https://doi.org/10.1016/j.molimm.2004.12.006

15. Boniotto M, Braida L, Spanò A, Pirulli D, Baldas V, Trevisiol C et al. Variant mannose-binding lectin alleles are associated with celiac disease. Immunogenetics. 2002;54(8):596-8. https://doi.org/10.1007/s00251-002-0504-2

16. Tsutsumi A, Sasaki K, Wakamiya N, Ichikawa K, Atsumi T, Ohtani $\mathrm{K}$, et al. Mannose-binding lectin gene: polymorphisms in Japanese patients with systemic lupus erythematosus, rheumatoid arthritis and Sjögren's syndrome. Genes Immun. 2001;2(2):99-104. https://doi.org/10.1038/sj.gene.6363744

17. Lhotta K, Würzner R, König P. Glomerular deposition of mannose-binding lectin in human glomerulonephritis. Nephrol Dial Transplant. 1999;14(4):881-6.

https://doi.org/10.1093/ndt/14.4.881

18. Huang YF, Wang W, Han JY, Wu XW, Zhang ST, Liu CJ et al. Increased frequency of the mannose-binding lectin LX haplotype in Chinese systemic lupus erythematosus patients. Eur J Immunogenet. 2003;30(2):121-4. https://doi.org/10.1046/j.1365-2370.2003.00370.x

19. Perazzio SF, Silva NP, Carneiro-Sampaio M, Andrade LE. Mild and moderate Mannose Binding Lectin deficiency are associated with systemic lupus erythematosus and lupus nephritis in Brazilian patients. Rev Bras Reumatol Engl Ed. 2016;56(3):220-7. English, Portuguese. https://doi.org/10.1016/j.rbre.2016.01.002

20. Rabie RA, Ibrahim NF, Gebriel MG. Mannose-Binding Lectin Serum Level and Gene Polymorphism in Systemic Lupus Erythematosus Egyptian Patients. Egypt J Immunol. 2020;27(1):45-53.

21. Hayashi N, Okada K, Matsui Y, Fujimoto K, Adachi H, Yamaya $\mathrm{H}$ et al. Glomerular mannose-binding lectin deposition in intrinsic antigen-related membranous nephropathy. Nephrol Dial Transplant. 2018;33(5):832-40. https://doi.org/10.1093/ndt/gfx235

22. Hisano S, Matsushita M, Fujita T, Iwasaki H. Activation of the lectin complement pathway in Henoch-Schönlein purpura nephritis. Am J Kidney Dis. 2005;45(2):295-302. https://doi.org/10.1053/j.ajkd.2004.10.020

23. Czerewaty M, Tarnowski M, Safranow K, Domanski L, Pawlik A. Mannose binding lectin 2 gene polymorphisms in patients after renal transplantation with acute graft rejection. Transpl Immunol. 2019;54:29-37. https://doi.org/10.1016/j.trim.2019.01.004

24. Ohsawa I, Ohi H, Tamano M, Endo M, Fujita T, Satomura A et al. Cryoprecipitate of patients with cryoglobulinemic glomerulonephritis contains molecules of the lectin complement pathway. Clin Immunol. 2001;101(1):59-66. https://doi.org/10.1006/clim.2001.5098

25. Guo WY, Zhu L, Meng SJ, Shi SF, Liu LJ, Lv JC et al. MannoseBinding Lectin Levels Could Predict Prognosis in IgA Nephropathy. J Am Soc Nephrol. 2017;28(11):3175-81. https://doi.org/10.1681/ASN.2017010076

26. Hovind P, Hansen TK, Tarnow L, Thiel S, Steffensen R, Flyvbjerg $A$ et al. Mannose-binding lectin as a predictor of microalbuminuria in type 1 diabetes: an inception cohort study. Diabetes. 2005;54(5):1523-7. 
https://doi.org/10.2337/diabetes.54.5.1523

27. de Vries B, Walter SJ, Peutz-Kootstra CJ, Wolfs TG, van Heurn LW, Buurman WA. The mannose-binding lectin-pathway is involved in complement activation in the course of renal ischemia-reperfusion injury. Am J Pathol. 2004;165(5):167788. https://doi.org/10.1016/S0002-9440(10)63424-4

28. Satomura A, Endo M, Ohi H, Sudo S, Ohsawa I, Fujita T et al. Significant elevations in serum mannose-binding lectin levels in patients with chronic renal failure. Nephron. 2002;92(3):702-4. https://doi.org/10.1159/000064089

29. Ohsawa I, Ohi H, Endo M, Fujita T, Matsushita M, Fujita T. Evidence of lectin complement pathway activation in poststreptococcal glomerulonephritis. Kidney Int. 1999;56(3):1158-9. https://doi.org/10.1046/j.1523-1755.1999.00642.x

30. Sethi S, Nasr SH, De Vriese AS, Fervenza FC. C4d as a Diagnostic Tool in Proliferative GN. J Am Soc Nephrol. 2015;26(11):2852-9. https://doi.org/10.1681/ASN.2014040406

31. Mahto H, Pati A, Sahu SK, Sharma HP, Padhi A, Panda AK. Association of MBL-2 gene polymorphisms with systemic lupus erythematosus: an updated meta-analysis and trial sequential analysis. Lupus. 2020;29(10):1227-37. https://doi.org/10.1177/0961203320939156
32. Xu J, Chen G, Yan Z, Qiu M, Tong W, Zhang X et al. Effect of mannose-binding lectin gene polymorphisms on the risk of rheumatoid arthritis: Evidence from a meta-analysis. Int J Rheum Dis. 2021;24(3):300-13.

https://doi.org/10.1111/1756-185X.14060

33. Tiyo BT, Vendramini ECL, de Souza VH, Colli CM, Alves HV, Sell AM et al. Association of MBL2 Exon 1 Polymorphisms With Multibacillary Leprosy. Front Immunol. 2020;11:1927. https://doi.org/10.3389/fimmu.2020.01927

34. Zhang JX, Gong WP, Zhu DL, An HR, Yang YR, Liang Y et al. Mannose-binding lectin 2 gene polymorphisms and their association with tuberculosis in a Chinese population. Infect Dis Poverty. 2020;9(1):46. https://doi.org/10.1186/s40249-020-00664-9

35. Dogan P, Ozkan H, Koksal N, Oral HB, Bagci O, Guney Varal I. Mannose-binding lectin gene polymorphism and its effect on short term outcomes in preterm infants. J Pediatr (Rio J). 2020;96(4):520-6. https://doi.org/10.1016/j.jped.2019.03.001

36. Malaquias MAS, Gadotti AC, Motta-Junior JDS, Martins APC, Azevedo MLV, Benevides APK et al. The role of the lectin pathway of the complement system in SARS-CoV-2 lung injury. Transl Res. 2021;231:55-63. https://doi.org/10.1016/j.trsl.2020.11.008

37. Ruiz P, Soares MF. Acute postinfectious glomerulonephritis: an immune response gone bad? Hum Pathol. 2003;34(1):1-2. https://doi.org/10.1053/hupa.2003.57 